\title{
Care in a new age: the work of caregivers with psychiatric patients in houses
}

\author{
Neila Sprioli ${ }^{1}$ \\ Maria Cristina Silva Costa²
}

The research aims to analyze the caregivers' work developed with psychiatric patients in assisted living facilities. The research used the ethnographic method and is theoretically based on Interpretative Anthropology for the analysis of the meanings of practices related to the caregiver's work in these residential devices. The techniques used in the research were participant observation and interviews. The main subjects of the search were the eleven caregivers and the secondary subjects were four supervisors. The results show the bond established between caregivers and residents, the possibility of a regular discussion under supervision, the impact of different equipments at the dwelling house on the daily reality of professionals and patients. The main conclusions permit recognizing the relevance of caregivers' work. Despite its deficient education, training and legal definition, this work supports behavioral changes observed in dwellers, which reveal the ongoing rehabilitation process.

Descriptors: Caregivers; Mental Health Assistance; Assisted Living Facilities; Rehabilitation.

\footnotetext{
${ }^{1}$ Occupational Therapist, Master's Student in Nursing, Escola de Enfermagem de Ribeirão Preto, Universidade de São Paulo, WHO Collaborating Centre for Nursing Research Development, SP, Brazil. E-mail: nsprioli@yahoo.com.br.

2 Ph.D. in Social Anthropology, Professor, Escola de Enfermagem de Ribeirão Preto, Universidade de São Paulo, WHO Collaborating Centre for Nursing Research Development, SP, Brazil. E-mail: mccosta@eerp.usp.br.
}

Corresponding Author:

Maria Cristina Silva Costa

Universidade de São Paulo. Escola de Enfermagem de Ribeirão Preto

Departamento de Enfermagem Psiquiátrica e Ciências Humanas

Av. dos Bandeirantes, 3900

Bairro: Monte Alegre

CEP: 14040-902, Ribeirão Preto, SP, Brasil

E-mail: mccosta@eerp.usp.br 


\section{Cuidar em novo tempo: o trabalho de cuidadores com pacientes psiquiátricos em moradias}

O objetivo deste estudo foi analisar o trabalho de cuidadores de pacientes psiquiátricos, em dois tipos de serviços residenciais terapêuticos. A pesquisa recorreu ao método etnográfico, baseado na teoria interpretativa, e utilizou as técnicas de observação participante e entrevistas em profundidade. Os sujeitos principais são onze cuidadores e os sujeitos secundários, quatro supervisores. Os principais achados consistem na identificação da formação e capacitação do cuidador; atividades pelas quais se responsabiliza e concepções sobre elas, mudanças desencadeadas nos serviços residenciais, vínculo que se estabelece entre cuidadores e moradores, possibilidade de discussão regular do trabalho em supervisão e impacto dos diferentes equipamentos de moradia no cotidiano de cuidadores e pacientes. As conclusões permitem reconhecer a relevância do trabalho dos cuidadores. Ainda que the falte melhor definição legal, formação e capacitação adequadas, este trabalho é o principal responsável pelas mudanças comportamentais observadas nos moradores, que permitem constatar o processo de reabilitação em curso.

Descritores: Cuidadores; Assistência em Saúde Mental; Moradias Assistidas; Reabilitação.

\section{Cuidar en tiempos nuevos: el trabajo de cuidadores con pacientes psiquiátricos en residencias terapéuticas}

El objetivo de este estudio fue analizar el trabajo de cuidadores con pacientes psiquiátricos en dos tipos de servicios en residencias terapéuticas. La investigación recurrió al método etnográfico, basado en la Teoría Interpretativa, y utilizó las técnicas de observación participativa y entrevistas en profundidad. Los sujetos principales son once cuidadores y los sujetos secundarios, cuatro supervisores. Los principales hallazgos consisten en: identificación de la formación y capacitación del cuidador; actividades por las cuales se responsabiliza y ; concepciones que tiene sobre ellas; cambios desencadenados en los servicios en residencias terapéuticas; vínculo que se establece entre cuidadores y residentes; posibilidad de discusión regular del trabajo en supervisión; e, impacto de los diferentes equipamientos de la residencia en lo cotidiano de cuidadores y pacientes. Las conclusiones permiten reconocer la relevancia del trabajo de los cuidadores. A pesar de que les falte mejor definición legal, formación y capacitación adecuada, este trabajo es el principal responsable por los cambios comportamentales observados en los residentes, que permiten constatar el proceso de rehabilitación en curso.

Descriptores: Cuidadores; Atención en Salud Mental; Instituciones de Vida Asistida; Rehabilitación.

\section{Introduction}

This study results from a research developed at Instituto Municipal Nise da Silveira, in Rio de Janeiro, Brazil $^{(1)}$. The institute, where renowned and innovative psychiatrics have already worked, has hosted new and important changes since the first decade of the $21^{\text {st }}$ century. Between 2000 and 2002, various changes started in the care offered to patients interned in the sectors of large infirmaries, typical of large asylums. As from 2003, reinforcing these changes, a project was set up - Housing Program - for which professionals with a higher education degree were hired to supervise a group of about 40 people, newly hired to work as caregivers. 
This research focuses on the caregivers' work. In the current psychiatric care context, the role of this character is hardly discussed in literature, but is fundamental to "deconstruct" the asylum apparatus, as well as to actually insert psychiatric patients in new care and treatment possibilities at assisted living facilities ${ }^{(2)}$.

These facilities start a profound change in the "treatment" patients/dwellers were offered, which used to be restricted to medication and containment, inside the infirmaries of psychiatric hospitals. Actions are introduced in some sectors, which entail the reduction of the damage deriving from long years of "institutionalization", considered as "the complex of 'damages' deriving from a forced long stay at the psychiatric hospital, when the institution is based on principles of authoritarianism and coercion. These principles, which give rise to the rules the patient should unconditionally submit to, express and determine a progressive loss of interest in that person which, through a process of regression and restriction of the I, induces to an emotional void"(3).

The institute's Housing Program proposed care inspired by new modes offered in line with the principles of the Psychiatric Reform. Therefore, it had to adapt to the changes in the perspective of psychiatry, mainly oriented at the rehabilitation of psychiatric patients, which "is not the replacement of disability by habilitation, but a set of strategies aimed at enhancing the opportunities to exchange resources and affection"(4).

The new proposal established actions like the recovery of citizenship by investigating patients' identity and making documentation feasible; medical treatment (in view of clinical complications deriving from age and even those produced during years of excessive medication use); regular and individual psychiatric consultations, including drug reassessment; enhancement of dwellers' autonomy in their daily activities; insertion of dwellers in daily care services and many others. All of these proposals were intended to introduce the dwellers into a new daily reality, as opposed to institutionalization, which would join housing and therapy and focus on rehabilitation, construction of the mental patient's citizenship and community insertion.

Work with psychiatric patients in common housing facilities (no longer in asylums only), which enhance richer daily experiences in psychosocial rehabilitation, should not only be characterized as a physical, structural change or a more humanized hotel management. Even if these changes are very important and permit visualizing the progress in psychiatric care, this work's reorientation towards mental patients' reinsertion in the community and the construction of their citizenship is more relevant.

Two types of public services associate care and housing: Assisted Living Facilities and "assisted housing". According to Brazilian legislation, Assisted Living Facilities (ALF) are inserted in the community and subordinated to the Psychosocial Care Center (CAPS) within the geographical area(5). Housing located inside psychiatric institutions is not considered as ALF. This type of housing, however, are also places where living turns into an important possibility to work with so-called "chronic" clients, through actions that enrich the daily life lost through the long institutionalization. By means of simple tasks, new possibilities are constructed there to take part in life and the community. Living in a place and being acknowledged in it.

In the new facilities, ALF and assisted housing, the greater meaning of care, i.e. attention or carefulness offered to something or someone, implies a series of daily actions(6). Today, the traditional object of nursing, care, involves the participation of different professional categories. In the care or assistance different types of housing provide, a worker stands out who is hardly known, rarely mentioned in specialized literature and even hardly recognized in housing service legislation: the caregiver.

The central aim of this paper is to analyze caregivers' work with psychiatric patients with a long history of institutionalization, at assisted living facilities.

\section{Methods}

In this qualitative research, the meaning of the practices and conceptions related to caregivers' work were subject to interpretative analysis, guided by the choice of the ethnographic method, with theoretical support from Interpretative Anthropology ${ }^{(7-8)}$. Like any ethnographic research, it is aimed at interpreting the meanings of conducts, conceptions, relations, and values, articulating them with the sociocultural context they are produced in.

In this study, ethnography is considered a method developed by a specific science, anthropology, and understood as "a dense description"(7), description in search of meanings. This ethnographic research followed the daily reality of housing services at the institute and apprehended caregivers' work with psychiatric patients as "webs of meanings"(7) to be interpreted. Thus, the method granted the researcher access to the interpretation the analyzed group itself formulated and offered the opportunity for the theoretically informed interpretation produced by the researcher ${ }^{(9-10)}$ 
The research was developed between 2008 and 2010 and included the retrospective approach of the residential services at Instituto Nise da Silveira, in Rio de Janeiro. The place of research consisted of the assisted housing facilities located inside the institute and the surrounding ALF (formerly subordinated to the institute and currently administered by the area CAPS).

Eleven caregivers were defined as the key research subjects, while four caregiver team supervisors served as secondary subjects and were the former's privileged interlocutors. The inclusion criteria were: working as a caregiver or service supervisor and accepting to participate. The number was defined based on the information saturation criterion.

Direct observation and in-depth interview techniques were prioritized, using succinct scripts. Observations were registered in field diaries, while interviews were recorded and later transcribed.

Interpretative analysis involved the identification of units of meaning through convergences and divergences among the collected data with the two groups of research participants. The following units of meaning were identified: assistance at the assisted housing facilities and ALF; the caregiver's work; training for care; the changes produced in the dwellers and facilities. The analysis attempted to integrate the meanings apprehended in the subjects' actions and conception into the conceptual structures that informed them and, thus, to guarantee their contextualization (culture understood as context)(7-8).

Approval for the research was obtained from the Institutional Review Board at Instituto Municipal Phillipe Pinel, Rio de Janeiro Municipal Government/Health Service Superintendence, registered under protocol $n$. 27 issued on $17 / 04 / 2008$. The study complied with the ethical recommendations of Resolution 196/96 and all participants signed the Informed Consent Term.

\section{Results and Discussion}

The results indicate convergences and divergences in the key and secondary subjects' conceptions and actions. In view of the distinction between caregivers' action and conceptions, however, more convergences than divergences were found, which was also the case for the secondary subjects. Among the two subject groups, particularities were revealed that indicated that supervisors apprehended caregivers' work more technically.

In the empirical research, some sources of satisfaction and disappointment produced in daily service reality were revealed, as well as the difficulties met, forms of acting and diverse understandings about the meaning of the work performed there.

The many interviews and observations produced material that clarified not only the different aspects and priorities present in the daily reality of assisted housing facilities and ALF, but also and mainly the work caregivers perform at these residential devices.

There are seven housing facilities inside the Instituto Municipal Nise da Silveira, administered by its Rehabilitation and Social Integration Group. With considerable distinction, these include a facility for one single dweller up to a pension with 42 inhabitants, as well as some intermediary facilities with 20 or 14 dwellers, whose structure is closer to that of a family house. There are five ALF located near the institute but subordinated to the CAPS, with four people living in each.

One of the most important convergences in the assessment caregivers and supervisors elaborated, which was also identified in the observation, revers to the influence of the service structure on care quality.

Caregivers and the supervisor responsible for the largest assisted housing facility eloquently address the problems of a large structure with an excessive number of dwellers (with quite distinguished health conditions), which intends to be a housing facility. In this case, the environment particularly hampers its management and the feasibility of a proposed individual look on the dwellers.

At the larger facilities, which preserve characteristics of infirmaries, i.e. hospitalization sites, like the two largest facilities inside the institute, the caregivers continue in a clear state of alert towards the house and the people circulating. In their bodily posture, facial expressions and conducts, these workers repeat other workers' behaviors from the former hospital infirmaries, where surveillance is essential.

The people living at the largest facilities, in turn, regularly walk from one side to the other, looking towards some point in the distance, unfamiliar with what is happening around them, in a circulating movement that seems to lack meaning. In smaller spaces, observation records describe dwellers leaving the room to go to the kitchen and eat, or go to the living room to watch television, as an example of circulation with defined meaning. People living at the smaller assisted housing facilities and ALF demonstrate greater mastering of the residential space than dwellers at the large institutional facilities. 
At the ALF, the characteristics of proximity and care, observed in the caregivers' actions when directly relating with the dwellers, are enhanced by the intimacy the space produces. This quality starts to facilitate the dwellers' appropriation of the space and its component objects, as verified in different ways, like when the researcher arrived to visit an ALF for example, was received by the people living there and saw them interrupting their activities, curious to see who was arriving and to know what she was doing. Similar behaviors were rarely identified at the institute's internal services, where the researcher's presence was not always observed or, when observed, this happened only for a moment, in a shortlasting attitude of curiosity.

The key and secondary subjects' reports, as well as the observation, indicate how the small number of rooms and people living at the house and the dwellers' possibility of greater freedom and interference in their homes are factors contributing to a higher care quality.

As for the caregivers' identification, most of them are nursing technicians (7). In other words, their educational background is a Professionalizing Secondary Education degree, although only a Primary Education degree is compulsory to serve as a caregiver. They are professionally registered as "caregivers". After being hired, many of them received training at the institute to deliver care to psychiatric patients at housing facilities. Among the supervisors, who served as secondary subjects, three are psychologists and one an occupational therapist, and all of them received previous training to deliver care at these facilities.

The search for a definition of caregivers' work in psychiatric care provides few results. Decrees Nos. 106 and 1220, both issued in 2000, created ALF as a care mode without specifying, however, how work will be accomplished. Only a concise citation refers to caregivers: "The caregiver plays an important role at the housing facility"(11), which implicitly entails the caregivers' monitoring of dwellers, but defines nothing about such an "important" task, nor does it characterize the professional who will put it in practice.

In fact, the "important task at the housing facility" the caregivers are in charge of, even if little known, could be proven through observation and interviews. The caregivers' daily monitoring of the dwellers includes psychosocial rehabilitation activities guided by housing, that is, the actions implicit in the "task" involve activities of daily living (ADLs) aimed at: stimulation of self-care, domestic management, leisure and assisted activities, among others. This is not an isolated task though; it is part of a team, as the key and secondary study subjects highlight.

In this team, the supervisory role gains relevance: When it's very urgent, I ask for help, right? I run to the supervisor, if I can't find the supervisor I turn to the coordinator, when it's something that can be solved I do it (C1).

It was observed that the supervisors' monitoring of the caregivers' actions enhances the guideline of this work, as a very relevant factor in the development and mainly in the continuity of the proposed actions.

For most caregivers, their work with the dwellers demands personal attributes like patience, ability to inspire confidence and manifestations of affection, as verified in this excerpt from an interview with a caregiver: They didn't have anyone to talk to. When the caregiver arrived, we gave them that attention. It was pain in the finger, headache, we showed interest, and went out with them... We turned to hospitals outside, to give them a better quality of life. Oh yes, proximity is important, because they need someone to trust. More than trust, it's a very strong bond I find very important for patients with disorders. And the caregiver's arrival already takes him a bit closer, because he leaves his home, his family, enters an infirmary and only meets people who only pay attention to the procedure. Caregivers get closer, are more kind to them ( $\mathrm{C} 10)$.

In this interview, the meanings the key research subjects predominantly attribute to their work can be identified. They reveal a care conception structured on feelings, proximity, confidence and bonding.

In the work of caregivers without specific training, whose knowledge is essentially based on experience, their experiences can be presented and can circulate across the housing facilities as activity proposals. "Knowhow" and "doing with" seem to get mixed and consecrate these professionals' work route. This results in actions potentially oriented towards self-knowledge, knowledge, subjectification, rehabilitation of the dwellers, but which can tend towards assistentialism when technical knowledge is not adequate for work. This reveals the great importance of supervisors' participation in daily work reality and systematic team discussions on the intended work guideline, aspects the supervisors and most caregivers value highly.

The meanings that can be apprehended based on the caregivers' testimonies reveal an understanding of care that is quite common among the main research subjects (and distanced from the conceptions the supervisors express). By associating care with kindness and patience, the former reveal an ordering logic based on feeling to grant meaning to their work object. 
Among the caregivers, the same feeling-based logic presides the meanings attributed to the conditions needed for care to take form. Ambiguously, to be accomplished, care conceived as teamwork depends on caregivers' personal attributes, which is revealed in the link between trust in the caregiver's person and the bonding necessary for care, as well as in the prioritization of personal qualities and direct relations, more than relations mediated by work and technical competency.

On the opposite, only one supervisor relates care with affection in an interview; all of them, on the other hand, talk about how the caregivers' work should be ruled and the need for technical knowledge that is rare among these professionals. The supervisors underline the need to create a sufficiently strengthened team dynamics to support the lack of the supposed "institutional support" given before, when the institution's custody determined what actions had to be performed with the dwellers.

Caregivers and supervisors underline the advances achieved through more individualized work at the facilities, including the dwellers' appropriation of spaces and objects, the return to social life in the community, valuation of clinical and psychic issues to be addressed or treated distinctively.

Among the convergences highlighted in the caregivers' conceptions, mainly those with previous experience at infirmaries, being in a house or a structured environment to approach this can make a big difference in work aimed at rehabilitation, as verified in the following statement: it's good because we have to deconstruct the asylum space, isn't it? He [the dweller] is entitled to say what's bad... if he doesn't want that food... isn't it? And have freedom... At the infirmary it was like that: just medicine, food, bathing and that's it. Here, they ask: where am I going to take a bath? Not now (C3).

The secondary subjects also mention the greater freedom patients conquered in the new services and value the power of expression, but eloquently add that patients gained autonomy, considered as the ability to manage their daily lives and make decisions.

The groups of interviewees almost unanimously agree that living in a house, no longer being a patient at a hospital infirmary, participating in the decisions one is affected by, not without difficulties, are guarantees of higher care quality and stimulate the dwellers' rehabilitation. Many (caregivers and supervisors) qualify these guarantees as greater freedom and participation. Among the supervisors, the valuation of dwellers' autonomy frequently appears. In their conceptions, freedom, participation and autonomy are linked with the sense of dwellers as interlocutors, negotiating on their existential conditions, even if often in a more limited way than they would like to. The dwellers' participation in a negotiation network constitutes a model that "puts participation instead of autonomy at the heart of questions, so that the aim is not to make the weak cease to be weak in order to compete with the strong, but to change the rules of the game, so that weak and strong players participate in permanent exchanges of competences and interests"(2).

Some of the difficulties caregivers and supervisors appointed, reflecting difficulties that affect any citizen (access to health, material needs etc.), go beyond the spatial structuring of the housing environment, whether inside an institution or inserted in the community, and which are inherent in the construction of the new. They approach many people's difficulty to acknowledge the citizenship and rights of former patients who now live in a community, as a supervisor clarifies: So, these are limits we face and that ends up demanding some entries... That's horrible... But the caregivers ask for them... "Ah, they're patients, isn't there a place?" or caregivers who already knew the doctors in the network, they manage to fit in another patient... We already went through severe issues because of that (S4).

By identifying various of the deadlocks and problems observed or reported as peculiar manifestations of new work, still under construction, the intent is to demonstrate here that the contingent, the unexpected and even old and known limits require the invention of conducts, in view of the inexistence of rules and action plans that cover the wide range of events managed in the daily reality of new experiences in different housing spaces.

Despite the problems, difficulties and deadlocks faces, the new care services permit the dwellers' slow and progressive conquest of freedom and autonomy on their way towards psychosocial rehabilitation. This basically results from the caregiver's work, through the accomplishment of activities of daily living.

Some examples of patients' progress, mentioned during the interviews, like now they take care of hygiene, may seem to attach too high a value to normative actions, towards adequate dressing, care or behavior. If one knows the daily reality of former infirmaries though, which radically silence patients at any large psychiatric hospital, one knows, in most cases, about the total deprival of human beings' characteristics, loss of identity and disability for simple daily actions and personal relations after a long stay. 
Thus, it is important to highlight that the changes in the dwellers' conducts the caregivers and supervisors detected and the researcher observed during the study go beyond simple or small changes; they are part of the conquest of possibilities for expression, life and recovery of a more dignified and multiple existence, inside or outside the institution.

These actions may seem very small to the eyes of people circulating in and dominating urban environments; for chronic patients who have been institutionalized for long periods though, the work aiming to construct new possibilities for life needs to be daily, regular, constant, long term, maybe forever.

The caregivers' conducts and conceptions, in addition to the supervisors' reports, point towards the need for continuous reflection on the housing service, a new service, put in practice by a task that produces constant changes, and therefore challenging and requiring innovations the workers themselves introduce.

It is perceived that the changed look can already enhance important modifications in work, as several caregivers mentioned: I work with dwellers instead of patients. This outlines care directed at promoting a more active posture in the non-patients.

\section{Conclusions}

The choice of the theme and the monitoring of caregivers' work was intended to focus on the importance of these professionals' task and the actual consequences of daily actions for the dwellers' lives.

The implantation of different decisions, decrees and strategies towards the definitive change of the Brazilian Mental Health model, based on the Psychiatric Reform, has involved various professional groups, from different areas, instead of just health, including the singular group of new caregiving professionals. The data collected in this research create yet another task for people who devise the Reform inside the institutions: that of looking at this newly emerged category and the consequences of their work.

Getting to know the caregivers' task at assisted living facilities implies acknowledging the importance of work that is lacking definition and better training, but which reveals a kind of availability and potential relation with psychiatric patients that seems to be capable of granting new perspectives to the losses that, at first sight, may seem irreversible. The guidelines for this work, on the one hand, are linked with those of assisted living facilities; on the other, supervision enhances them in the activity area, a very important function for the development and continuity of the proposed actions.

Despite primary education as the sole prerequisite for these caregivers' insertion into the residential facilities, there is a trend for the institution itself to enhance training for its workers, through courses and information lectures. It is verified, though, that their knowledge on mental illness, residential services and even care result much more from direct experience of these phenomena than from institutional training.

In summary, the changes detected in the people living at the assisted living facilities and TR under analysis are largely due to the caregivers' work and are part of the conquest of possibilities for expression, identity, freedom and meanings for life. Its greater sense, even if caregivers are hardly aware of this, is that of guiding oneself by the aims of rehabilitation, community reinsertion and construction of citizenship for mental patients.

\section{References}

1. Sprioli N. Cuidar em Novo Tempo: o trabalho de cuidadores profissionais com pacientes psiquiátricos em moradias. [Mestrado]. Ribeirão Preto (SP): Escola de Enfermagem de Ribeirão Preto da Universidade de São Paulo; 2010. 112 p.

2. Honorato CEM, Pinheiro R. O "cuidador da desinstitucionalização": o trabalho político no cotidiano das equipes de saúde mental nos Serviços Residenciais Terapêuticos. In: Pinheiro R, Guljor AP, Gomes A, Mattos RA de, organizadores. Desinstitucionalização da saúde mental. Rio de Janeiro: UERJ; IMS; ABRASCO; 2007. p. 169-88.

3. Amarante PDC. O homem e a serpente: outras histórias para a loucura e a psiquiatria. Rio de Janeiro: Fiocruz; 1996.

4. Basaglia F. A instituição negada: relato de um hospital psiquiátrico. Rio de Janeiro: Graal; 1991.

5. Ministério da Saúde (BR). Legislação em Saúde Mental, Série E, n.4. Brasília (DF) MS; 2002.

6. Scarcelli IR. Os sentidos do morar e a cidade: um olhar sobre os Serviços Residenciais Terapêuticos. Cad IPUB. 2006;12(22):71-81.

7. Geertz C. A Interpretação das Culturas. Rio de Janeiro: Zahar; 1978.

8. Geertz C. O Saber Local. Novos Ensaios de Antropologia Interpretativa. Petrópolis: Vozes; 1999.

9. Romanelli G. A entrevista antropológica: troca e alteridade. In: Romanelli G, Biasoli-Alves ZMM, 
organizadores. Diálogos Metodológicos sobre Prática de Pesquisa. Ribeirão Preto: Legis Summa; 1998.

10. Costa MCS. Intersubjetividade e historicidade: contribuições da moderna hermenêutica à pesquisa etnográfica. Rev. Latino-Am. Enfermagem. 2002;10(3):372-82.

11. Ministério da Saúde (BR). Residências Terapêuticas. Para quem precisa de cuidados em saúde mental, o melhor é viver em sociedade. Brasília (DF): MS; 2004. 